\title{
ANALISIS EFEKTIVITAS SISTEM INFORMASI AKUNTANSI DAN PENGENDALIAN INTERNAL PERKREDITAN PADA PT. BANK PEMBANGUNAN DAERAH PAPUA CABANG MANADO
}

\author{
Sonaria Krar ${ }^{1}$, Jantje. J. Tinangon ${ }^{2}$, Hendrik Gamaliel ${ }^{3}$ \\ ${ }^{1,2,3}$ Jurusan Akuntansi, Fakultas Ekonomi dan Bisnis, Universitas Sam Ratulangi, Jl.Kampus Bahu, Manado, \\ 95115, Indonesia \\ E- mail: Rhyakrar@gmail.com
}

\begin{abstract}
A good Accounting Information System can help company to provide the company's need for other information related to busyness process that exist within the company. This research study at PT. Regional bank development papua branch manado.This study aims to know effectiveness of information accounting system and internal control of kredit on PT.regional bank development papua branch manado.This study used a deskriptive qualitative method is a method that is done by classifying data and inormation which is obtained by various technicques such as survey, interviews, and others. So get a relevant conclusion.The results of the analysis of the conclusion that the information system and internal control of PT. bank Papua manado branch has been running well, and in accordance with procedures that have been set by the bank indonesian. Allready meet the characteristics and elements of internal control. Keywords : Information Accounting System, Internal control, Credit.
\end{abstract}

\section{PENDAHULUAN}

Dalam perubahan dan perkembangan teknologi yang pesat saat ini, suatu organisasi atau perusahaan dalam hal ini, suatu bank sudah harus sigap dalam mengatasi perubahanperubahan yang terjadi harus selalu siap menghadapi perubahan yang terjadi setiap saat. Dan banyak hal yang dapat di lakukan perusahaan untuk mewujudkan tujuan, salah satunya adalah dengan meningkatkan efektivitas sistem informasi akuntansi dan pengendalian yang ada pada perusahaan agar lebih efektif sesuai dengan tujuan perusahaan.

Perusahaan seperti perbankan melakukan kegiatan usaha bisnis untuk mencapai tujuan, dan tujuan perusahaan yaitu, mendapatkan laba. Bank juga sudah seharusnya mempertahankan dan terus melakukan pembenahan ke arah yang lebih baik pada manajemen. dan juga berusaha agar membuat sesuatu yang baru dalam persaingan dengan mengembangkan kinerja. Dalam rangka memperoleh kinerja yang baik adalah, dengan terus melakukan pembenahan sistem informasinya dan juga menambah kapasitas dan volume sumberdaya manusia yang terpercaya dan mempunyai kompetensi demi kepentingan organisasi. Bank daerah merupakan jenis bank yang ikut serta berfungsi dalam menggerakan perekonomian terlebih khusus daerah. Salah satu kegiatan sebuah bank atau organisasi adalah penyaluran kredit kepada masyarakat dalam bentuk kredit konsumtif maupun kredit produktif. Sistem Informasi Akuntansi berhubungan dengan penyediaan informasi untuk organisasi atau perusahaan. sistem informasi akuntansi adalah salah satu bagian terpenting dari seluruh informasi yang di perlukan oleh pihak manajemen. Salah satu peran penting sistem informasi akuntansi adalah menyajikan informasi bagi para penggunanya secara baik dan benar. Suatu manajemen dalam sebuah perusahaan membutuhkan data atau informasi yang berbeda menurut tugas dan tanggungjawab yang di milikinya. Dalam hal ini, manajemen membutuhkan informasi terperinci dalam melaksanakan suatu kegiatan. 
Sebaliknya, maka semakin tinggi tingkat manajemen memerlukan informasi yang lebih ringkas. Kualitas informasi akuntansi yang di sajikan dalam bentuk laporan keuangan dapat di gunakan dalam pengambilan keputusan. Bagian pelaporan di tuntut agar memberikan informasi yang akurat.

PT. Bank Pembangunan Daerah Papua adalah salah satu bank daerah dimana dananya di himpun dari pemerintah daerah dan masyarakat. Keberadaan bank papua memiliki peran yang sangat penting dalam mendorong pembangunan dan meningkatkan pertumbuhan perekonomian di beberapa daerah terlebih khusus di Papua. Oleh karena itu, Perkembangan bank papua dari berbagai aspek di tuntut untuk melakukan perubahan dan perbaikan terutama dalam mengelola kegiatan usaha bisnis. Hal ini di maksudkan untuk memberikan tingkat kepercayaan masyarakat atas keberadaan bank papua dan demi keberlanjutan perusahaan. Namun, permasalahan perusahaan dalam perkreditan yaitu bagaimana meminimalisir risiko kredit macet yang terjadi. Tingginya NPL di picu perubahan pola pemberian kredit bank papua dari kredit konsumtif Berdasarkan uraian latar belakang masalah di atas maka, peneliti tertarik untuk menganalisis efektivitas Sistem Informasi Akuntansi dan Pengendalian internal perkreditan pada PT. Bank Pembangunan Daerah Papua Cabang Manado.

\section{TINJAUAN PUSTAKA}

Akuntansi Manajemen. Dalam ilmu akuntansi yang sedang berkembang pesat, dan terbagi menjadi beberapa bagian salah satunya akuntansi manajemen. Akuntansi manajemen( management accounting) merupaan bidang ilmu akuntansi yang mempelajari tentang bagaimana cara untuk menghasilkan data keuangan bagi organisasi selanjutnya, akan di ambil guna pengambilan keputusan. Menurut Krismiaji dan Aryani(2011) akuntansi manajemen adalah, salah satu cabang ilmu akuntansi yang menghasilkan informasi untuk manajemen atau pihak intern perusahaan. menyusun perencanaan, dan sistem manajemen kinerja, serta menyediakan keahlian dalam pelaporan keuangan dan pengendalian untuk membantu manajemen dalam memformulasikan serta mengimplementasikan suatu strategi organisasi. Akuntansi manajemen di butuhkan untuk menyediakan informasi, yang di perlukan oleh manajemen guna melakukan proses manajemen. hasil dari akuntansi manajemen berupa keputusan di bidang keuangan, salah satu contoh misalnya, perusahaan mempunyai asset yaitu,tanah yang belum di gunakan, maka asset itu akan di pakai maka dalam hal ini akuntansi manajemen akan membuat keputusan tanah itu akan di pakai sendiri atau di sewakan, mana yang lebih menguntungkan. Akuntansi manajemen di gunakan oleh manajemen dalam melakukan dua fungsi manajemen yaitu, perencanaan, dan pengendalian aktivitas di masa mendatang.

Konsep Sistem Informasi Akuntansi. Setiap perusahaan mempunyai tujuan yang berbeda-beda, sesuai dengan jenis dan ruang lingkupnya. Namun, pada akhirnya akan mengarah kepada tujuan utamanya yaitu, memperoleh laba. Untuk mencapai tujuan tersebut seorang pemimpin harus mengambil keputusan yang tepat di antara alternatif yang akan di proses. Pengambilan keputusan manajemen membutuhkan informasi yang andal mengenai aktivitas- aktivitas yang terjadi di organisasi. Sistem informasi akuntansi merupakan salah satu bagian terpenting dari seluruh informasi yang di perlukan oleh pihak manajemen.

Konsep Pengendalian Internal. Pengendalian internal adalah istilah yang telah umum dan banyak di pergunakan dalam bentuk variasi kepentingan dan definisi. Dan juga manfaatnya cukup penting dari di karenakan perusahaan berkembang. Pengendalian internal merupakan rencana organisasi atau teknik yang di gunakan dalam hal menjaga dan menjaga aktiva, menghasilkan informasi yang 
sangat benar serta dapat di percaya, memprediksi efisien dan tidaknya kegiatan, dan juga sebagai dorongan agar aturan atau kebijakan manajemen di taati. Adapun konsep umum dari pengendalian antara lain :

1. Pengendalian manajemen (management control) merupakan, konsep yang lebih luas di bandingkan dengan pengendalian internal, yang memiliki karakteristik sebagai berikut: merupakan bagian yang integral dari tanggungjawab suatu organisasi, di rancang guna meminimalisir terjadinya kesalahan, dan untuk mencapai tujuan organisasi, dan beriorientasi bagi pegawai dan mencoba membantu pegawai dalam mencapai sasaran dengan menaati peraturan di perusahaan. Pengendalian Administrasi, merupakan pengendalian yang menjamin agar kegiatan efisien serta ketaatan terhadap peraturan yang di berlakukan manajemen.

2. Pengendalian Akuntansi (accounting control) merupakan pengendalian yang berfungsi membantu melindungi asset, dan menjamin akurasi dan daya andal catatan keuangan perusahaan.

3. Struktur pengendalian intern merupakan, kebijakan dan peraturan yang di tetapkan guna memberikan jaminan yang layak terhadap tujuan khusus organisasi yang ingin dicapai. Struktur pengendalian ini mempunyai tiga unsur antara lain, lingkungan pengendalian, sistem akuntansi, prosedur pengendalian. Para manajer perusahaan harus mampu menilai sistem internal karena mereka bertanggungjawab atas pengendalian internal pelaporan keuangan perusahaan.

Pengertian Kredit. Undang-undang perbankan no.10 tahun 1998 (Khasmir 2012:112) kredit merupakan penyediaan uang atau tagihan yang dapat di persamakan dengan itu berdasarkan persetujuan atau kesepakatan pinjam meminjam antara bank dan pihak lain yang mewajibkan pihak peminjam melunasi utangnya setelah jangka waktu tertentu dengan pemberian bunga. Istilah kredit sendiri berawal dari bahasa yunani credere yang artinya kepercayaan (truth atau faith). Oleh sebab itu, dasar dari kredit yaitu, kepercayaan. Seseorang atau suatu badan usaha yang memberikan kredit percaya bahwa penerima kredit(debitur) pada waktu yang akan datang akan sanggup memenuhi semua yang sudah di janjikan. Perjanjian itu dapat berupa barang, uang, atau, jasa. Dengan demikian, prestasi dan kontraprestasi dapat berbentuk barang terhadap barang, barang terhadap uang, barang terhadap jasa, jasa terhadap jasa, jasa terhadap uang, jasa terhadap barang, uang terhadap uang,uang terhadap barang dan uang terhadap jasa.

Penelitian Terdahulu. Priyono (2012),Analisis Efektivitas Sistem Pengendalian Intern pada Proses Pemberian Kredit Mikro Pada PT.Bank Syariah Mandiri ManadoAnalisis Proses Pemberian Kredit yang sesuai dengan prinsip kehati-hatian dan asas Perkreditan yang sehat Pada Bank Metode Deskriptif Hasil penelitian bank memiliki sistem pengendalian intern yang efektif ini dapat di lihat dari elemen struktur pengendalian yang sudah membaik. Tjodi (2016),Analisis Sistem Pengendalian Internal Piutang Usaha pada PT. Bank Sulut-Go KCP Ranotana.Tujuan penelitian ini adalah untuk menganalisis sistem pengendalian internal piutang usaha pada PT. Bank Sulut-Go KCP Ranotana dan apakah sesuai dengan prinsip-prinsip COSO Berdasarkan analisis sistem pengendalian internal atas piutang usaha pada PT.Bank Sulut-Go KCP Ranotana diperoleh bahwa sistem pengendalian internal atas piutang usaha telah berjalan dengan baik.

\section{METODE PENELITIAN}

Jenis Penelitian. Jenis penelitian yang digunakan dalam penelitian ini adalah metode deskriptif kualitatif. Penelitian ini di lakukan melalui pembuatan suatu uraian sistematis berdasarkan data- data yang di ambil. 
Tempat dan Waktu Penelitian. Penelitian ini di lakukan pada PT. Bank Pembangunan Daerah Papua cabang manado yang Beralamat komp. Megamas Ruko Mega Bright Blok 1 E No. 3 manado - Sulut dengan waktu penelitian Yaitu pada Bulan Desember 2017- Februari 2018.

\section{Jenis, Sumber, dan Metode Pengumpulan Data \\ Jenis Data 1. Data Kualitatif \\ 2. Data Kuantitatif}

Sumber Data. Data primer adalah data yang di peroleh langsung dari sumbernya dengan cara survey lapangan, di amati, dan di catat oleh peneliti dengan menggunakan semua metode pengumpulan data original. Data sekunder adalah data yang diperoleh penulis melalui literatur-literatur yang ada. atau buku-buku berupa dokumentasi dan dari perpustakaan yang di gunakan sebagai acuan teoritis dalam pembahasan. Sumber data yang di gunakan dalam penelitian ini adalah data primer. Data primer yang di butuhkan merupakan data yang di peroleh langsung dari para responden perusahaan.

Metode Pengumpulan Data. Metode pengumpulan data sehingga penyajian dapat di lakukan dengan baik maka, di perlukan metode yang benar. Dengan demikian dalam penelitian ini di tempuh melalui beberapa cara antara lain :

1. Dokumentasi yaitu, pengumpulan data didapat dari pengumpulan data dan informasi melalui dokumen yang berbentuk tulisan yaitu, sejarah, aturan, dan kebijakan perusahaan.

2. Wawancara tak terstruktur, yang berupa mengajukan pertanyaan bebas atau tanpa pola yang di tentukan terlebih dahulu.

3. Teknik perpustakaan yaitu, berupa data yang di ambil melalui teori-teori dari literatur yang behubungan dengan judul penelitian.

Metode Analisis Data. Metode yang di gunakan dalam penelitian ini adalah metode deskriptif. Metode deskriptif merupakan suatu cara pembahasan yang terlebih dahulu mengambil data yang ada dan di klarifikasi, di analisis, selanjutnya di interpretasikan sehingga dapat memberikan gambaran yang jelas mengenai keadaan yang di teliti.

\section{HASIL PENELITIAN DAN PEMBAHASAN}

\subsection{Hasil Penelitian}

Bank Papua yang sebelum menjadi Perseroan Terbatas bernama Bank Pembangunan Daerah Irian Jaya, didirikan pada tanggal 13 April 1966 berdasarkan Surat Keputusan Gubernur Kepala Daerah Tingkat I Irian Barat Nomor: 37/GIB/1966 dan disahkan menjadi peraturan Daerah Provinsi Irian Barat Nomor 1 Tahun 1970 tanggal 23 Maret 1970, pada lembaran Daerah Provinsi Irian Barat No. 42 Tahun 1970, kemudian sesuai Surat KeputusanMenteri Keuangan RI No.Kep.283/ DDK/II/1972 tanggal 15 Juli 1972 tentang pemberian izin usaha Bank Pembangunan Daerah Irian Barat berkedudukan di Jayapura melaksanakan operasional sebagaimana Bank Umum lainnya dengan modal dasar pertama kali ditetapkan sebesar Empat Juta. Bank Pembangunan daerah papua didirikan Dengan visi menjadi bank komersial yang kuat, unggul, dan terpercaya, sehingga PT.bank papua resmi membuka cabang di kota manado Sulawesi utara 11 februari 2014. Dengan lima tujuan utama yaitu, mendukung program pemerintah Sulawesi utara, papua, dan papua barat untuk menjadikan papua bangkit mandiri, dan sejahtera, dan juga membantu mempersingkat jalur transaksi keuangan masyarakat daerah manado dan sebaliknya. Tujuan terakhir agar dapat membantu menciptakan peluang bisnis bagi masyarakat setempat, mengingatkan juga bahwa Sulawesi Utara di kenal dengan keindahan 
alam lautnya, dan bisa menjadikan Papua sebagai salah satu tujuan bagi para wisatawan.

\section{Akuntansi pada prosedur Sistem Informasi Perkreditan Pada PT. Bank} Papua Cabang Manado. Sistem Informasi Akuntansi pada Proses Perkreditan PT. BPD Papua Cabang Manado. PT. BPD Papua Cabang Manado memahami bahwa Sistem Informasi Akuntansi yang diterapkan pihak manajemen adalah alat yang dapat mempermudah manajemen bank guna melakukan kegiatannya, terlebih proses penyaluran pinjaman kepada calon nasabah atau debitur. Sehingga dalam memastikan efektivitas dalam Sistem Informasi Akuntansinya, PT. Bank Pembangunan Daerah Papua Cabang Manado mempunyai elemen -elemen penting yang terdapat dalam proses penyaluran pinjaman kepada para debitur dapat di lihat dari:

1. Dokumen yang memadai.

2. Komputer dan Teknologi Informasi.

3. Proses realisasi pinjaman.

Dan juga sistem penyaluran kredit bank papua cabang manado terdapat beberapa proses penyaluran kredit yang sudah cukup berjalan baik yaitu : proses pengajuan permohonan kredit, pengecekan kembali, persetujuan, pencairan, pembayaran, dan pengembalian pinjaman dalam waktu yang di tentukan.

Tabel 1. Skor presentase efektivitas sistem informasi akuntansi pemberian kredit yang memadai

\begin{tabular}{clcc}
\hline Responden & \multicolumn{1}{c}{ Alternatif Jawaban } & Jumlah & Presentase \\
\hline \multirow{2}{*}{15} & Sangat setuju & 9 & $88,33 \%$ \\
& Setuju & 5 & \\
& Tidak setuju & 1 & \\
& Sangat tidak setuju & 0 & $100 \%$ \\
\hline
\end{tabular}

Sumber: Data Olahan

Berdasarkan hasil kuesioner sistem informasi akuntansi pemberian kredit maka dari seluruh jawaban kuesioner terdapat presentase sebesar 88,33 maka, dapat di simpulkan bahwa sistem informasi akuntansi pemberian kredit pada Bank Papua Cabang Manado cukup memadai.

Pengendalian Internal pada Prosedur Pemberian Kredit PT. Bank Papua Cabang Manado. Adapun pemberian kredit pada PT. Bank Pembangunan Daerah Cabang Manado sudah berjalan dengan baik, hal ini dapat dilihat dari faktor-faktor yang mendukung hasil analisis tersebut yaitu menganalisis dengan menggunakan metode penilaian elemen pengendalian internal.

1. Lingkungan Pengendalian pada proses penyaluran kredit faktor-faktor terlihat pada: (a) Bagian - bagian Organisasi yang sudah ada; (2) otoritas wewenang dan tanggung jawab; (3) prosedur dalam melatih Sumber daya baik manusia maupun peralatan; dan (4) etika, intregitas serta budaya pada PT. Bank Papua Cabang manado. Pada komponen ini mencerminkan keseluruhan komitmen, perilaku, kepedulian dan langkalangkah dewan komisaris dan direksi bank dalam melaksanakan kegiatan pengendalian operasional bank serta menciptakan suatu kultur organisasi. Bank mengenai pentingnya pengendalian internal yang berlaku di bank. Faktor yang mempengaruhi pengawasan oleh manajemen dan kultur jaringan adalah dewan komisaris, direksi, dan budaya pengendalian. Pengawasan oleh Manajemen dan Kultur Pengendalian dapat terwujud dengan baik apabila diterapkan prinsip dalam pelaksanaan pengendalian internal. 
Tabel 2. Skor Presentase Lingkungan Pengendalian

\begin{tabular}{cccc}
\hline Responden & Alternatif Jawaban & Jumlah & Presentasi \\
\hline 15 & Sangat setuju & 9 & $88,33 \%$ \\
& Setuju & 5 & \\
& Tidak setuju & 1 & \\
Total & Sangat tidak setuju & 0 & $100 \%$ \\
\hline
\end{tabular}

Sumber: Data Olahan

Berdasarkan hasil skor lingkungan pengendalian diatas maka yang secara keseluruhan jawaban kuesioner menghasilkan nilai presentase sebesar $88,33 \%$ hal itu menunjukkan lingkungan pengendalian internal kredit tergolong cukup baik.

2. Penaksiran Risiko. Analisis atau Penilaian risiko, yang di hadapi bank untuk mencapai sasaran usaha yang di tetapkan. Penilaian risiko guna mengidentifikasi dan mengelola risiko penilaian risiko pada penelitian ini Penaksiran risiko. Penilaian risiko guna mengidentifikasi dan mengelola risiko. Penilaian risiko pada penelitian ini mengkhususkan pada risiko pemberian kredit yang melekat pada aktivitas marketing Bank Papua Cabang Manado. Pelaksanaan analisis pemberian kredit pada PT. Bank Pembangunan Daerah Cabang Manado sudah dilaksanakan dengan baik, sehingga analisis yang di lakukan di harapkan dapat membantu dalam menghasilkan keputusan yang efektif dalam merealisasikan kredit kepada debitur. Analisis kredit yang dilakukan oleh bagian departemen kredit dimana proses pada PT. Bank Pembangunan Daerah Cabang Manado Pelaksanaan analisis dapat dilakukan dengan meninjau dari dokumen yang diajukan. Serta dalam prosedur dengan di lihat dari aspek hukum, aspek pemasaran, aspek keuangan, aspek operasi, aspek sosial dan ekonomi. dan juga manajemen harus menentukan tujuan yang sesuai dengan sasaran usaha yang ditetapkan dan melakukan penilaian risiko secara berkelanjutan guna pencapaian sasaran atau meminimalisir kredit bermasalah. Merujuk pada hal tersebut, Bank Papua Cabang Manado mengacu pada visi misi, perusahaan Bank Papua secara keseluruhan. Artinya, tujuan itu mengacu kepada visi misi bank itu sendiri tidak bisa mengatur diri sendiri tapi dia tetap mengacu kepada Bank Papua secara keseluruhan. Terkait penilaian risiko berkelanjutan guna pencapaian sasaran dilakukan Bank Papua dengan mengidentifikasi dan menilai semua risiko yang dihadapi setiap saat.

Tabel 3. Skor Presentase Penaksiran Risiko

\begin{tabular}{cccc}
\hline Responden & Alternatif Jawaban & Jumlah & Presentase \\
\hline 15 & Sangat setuju & 11 & $91,66 \%$ \\
& Setuju & 3 & \\
& Tidak setuju & 1 & \\
Total & Sangat tidak setuju & 0 & $100 \%$ \\
\hline
\end{tabular}

Sumber: Data Olahan

Berdasarkan hasil Skor Penaksiran Risiko diatas dan keseluruhan jawaban kuesioner menghasilkan nilai presentase sebesar 91,66\%. Hal itu menunjukkan pengendalian internal kredit (penaksiran risiko) tergolong cukup baik.

3. Aktivitas pengendalian. Pada aktivitas penyaluran kredit pada PT. Bank Pembangunan Daerah Cabang Manado, dapat terlihat dari Sistem Informasi Akuntansi, antara lain :

a. Pelatihan atau pembinaan pegawai agar dapat meningkatkan kinerja. 
b. Pemisahaan tugas dan tanggung jawab dalam aktivitas pemberian kredit pada PT. Bank Papua Cabang Manado.

c. Dokumen, teknologi, dan pelaporan yang cukup dalam untuk membantu pencatatan atas laporan kejadian dan transaksi pada proses penyaluran pinjaman.

Tabel 4. Skor Presentase Aktivitas Pengendalian

\begin{tabular}{cccc}
\hline Responden & Alternatif Jawaban & Jumlah & Presentase \\
\hline 15 & Sangat setuju & 13 & $96,6 \%$ \\
& Setuju & 2 & \\
& Tidak setuju & 0 & \\
Total & Sangat tidak setuju & 0 & $100 \%$ \\
\hline
\end{tabular}

Sumber: Data Olahan

Berdasarkan hasil skor aktivitas pengendalian diatas maka secara keseluruhan jawaban kuesioner menghasilkan nilai presentase sebesar 96,6\% hal itu menunjukkan pengendalian internal kredit (aktivitas pengendalian) tergolong baik.

4. Informasi dan Komunikasi. Informasi dan komunikasi bertujuan mengetahui risiko yang dapat timbul dan digunakan sebagai bahan bertukar informasi pada aktivitas pelaksanaan tanggung jawab dan wewenang pihak manajemen. Pada PT.Bank papua cabang manado dalam hal mengatur informasi akuntansi kredit dalam hal ini, pengakuan dan penyajian informasi mengacu pada Standar akuntansi keuangan. dan juga komunikasi pada penyaluran kredit, yaitu memberikan pengertian yang cukup jelas tentang proses penyaluran kredit, antara lain dengan metode yang memperlihatkan proses sekaligus alur dalam mempermudah pekerjaan bagi setiap departemen terkait dan Terlebih pada bagian perkreditan.

Tabel 5. Skor Presentase Informasi dan Komunikasi

\begin{tabular}{cccc}
\hline Responden & Alternatif Jawaban & Jumlah & Presentase \\
\hline 15 & Sangat setuju & 7 & $83,33 \%$ \\
& Setuju & 6 & \\
& Tidak setuju & 2 & \\
Total & Sangat tidak setuju & 0 & $100 \%$ \\
\hline
\end{tabular}

Sumber: Data Olahan

Berdasarkan hasil Skor Informasi dan Komunikasi diatas,secara keseluruhan jawaban kuesioner menghasilkan nilai presentase sebesar83,33\% hal itu menunjukkan pengendalian internal kredit (informasi dan komunikasi) tergolong sangat baik.

5. Pemantauan atau monitoring. Pemantauan atau monitoring, digunakan perusahaan agar mengetahui apakah tiap-tiap dari lima elemen pengendalian internal, termasuk pengendalian terhadap prinsip-prinsip dari setiap elemen untuk meyakinkan bahwa dalam penyaluran kredit telah sesuai dengan aturan penyaluran kredit sampai pada waktu pengembalian. 
Tabel 6. Skor Presentase Monitoring atau Pengawasan

\begin{tabular}{cccc}
\hline Responden & Alternatif Jawaban & Jumlah & Presentase \\
\hline 15 & Sangat setuju & 12 & $93,33 \%$ \\
& Setuju & 2 & \\
& Tidak setuju & 1 & \\
Total & Sangat tidak setuju & 0 & $100 \%$ \\
\hline
\end{tabular}

Sumber: Data Olahan

Berdasarkan hasil Skor Monitoring atau Pengawasan diatas, secara keseluruhan jawaban kuesioner menghasilkan nilai presentase sebesar93,33\% hal itu menunjukkan pengendalian internal kredit (monitoring dan pengawasan) tergolong sangat baik.

\subsection{Pembahasan}

Berdasarkan hasil penelitian Bank Papua Cabang Manado telah memiliki kebijakan dan prosedur yang secara tertulis berupa SOP untuk otorisasi dan persetujuan setiap transaksi yang berhubungan dengan kredit. Dan Sistem informasi akuntansi dan Pengendalian Internal perkreditan dapat di lihat dari:

a. Lingkungan pengendalian, untuk kesamaan prosedur lingkungan pengendalian dari pengendalian intern secara keseluruhan, yang di terapkan telah berjalan baik, namun harus melakukan pembenahan dalam prosedur pemberian kredit. PT. Bank Papua mempunyai tujuan, visi, misi, serta Budaya Kerja,yang akan berkelanjutan.

b. Aktivitas Pengendalian internal merupakan bentuk proses yang telah di lakukan guna menanggulangi risiko yang di hadapi bank. Yang bertujuan untuk mencapai tujuan manajemen bank itu sendiri. Aktivitas pengendalian yang telah di laksanakan oleh bank papua cabang manado adalah review terhadap kinerja, prosedur pemberian kredit, dan audit mutu internal.

c. Penilaian risiko, pada bank papua cabang manado oleh karena suatu pengambilan keputusan yang baik, harus melalui prosedur dan persetujuan dari PT. Bank papua cabang manado tetapi pada pelaksanaan operasional sehari-hari manajemen sudah menetapkan tahapan yang akan di gunakan dalam menghadapi risiko yang timbul dari situasi pegawai baru, teknologi, serta kredit bermasalah.

d. Informasi dan Komunikasi, Pengendalian intern sistem informasi dan komunikasi yang terhubung di bank papua di lakukan dengan media rapat secara periodik antar pihak- pihak yang berkepentingan yang di dalamnya terutama kepala cabang dan departemen kredit. Dengan tujuan untuk menjalin komunikasi antar bagian yang berkepentingan agar menyampaikan risiko - risiko dan laporan yang mungkin timbul selama jalannya proses pemberian kredit Bank Papua cabang manado.

e. Pengawasan atau monitoring, yang diterapkan kepada kinerja Pegawai yang dilaksanakan dari tingkatan Kepala cabang hingga kepala bagian dari tiap-tiap departemen operasional. Di samping itu, juga monitoring yang di lakukan Direktur Utama PT. Bank Pembangunan Daerah Papua pusat sebagai peningkatan kinerja Direktur utama dalam memimpin manajemen Bank papua secara umum .

\section{KESIMPULAN DAN SARAN}

\subsection{Kesimpulan}

Dari hasil Penelitian terhadap pelaksanaan Sistem Informasi Akuntansi dan Pengendalian Internal Perkreditan PT.Bank Papua Cabang Manado kesimpulannya adalah:

1. Sistem Informasi Akuntansi penyaluran kredit yang di terapkan sudah cukup baik, karena hal tersebut di dukung oleh Sistem Informasi Akuntansi yang sudah terkomputerisasi. 
Disamping itu, dalam prosedur operasional pemberian kredit terdapat prosedur-prosedur, yang bertujuan untuk menghindari terjadinya risiko dalam perkreditan. Serta sudah memenuhi karakteristik dan elemen Sistem Informasi Akuntansi antara lain, sumberdaya manusia, proses penyaluran kredit, dan teknologi yang ada.

2. Pengendalian Internal Perkreditan pada PT. Bank Pembangunan Daerah Papua Pengendalian Internal Perkreditan yang dijalankan sudah berjalan baik dan efektif yaitu, yang meliputi unsur: lingkungan pengendalian, penaksiran risiko, kegiatan pengendalian, komunikasi dan informasi, dan pemantauan. Di tinjau dari prosedur pemberian kredit sudah ada pemisahan fungsi yang jelas dalam standar operasional pemberian kredit. Bank Papua Cabang Manado juga dalam hal ini audit yang dilakukan oleh staff audit internal.

\subsection{Saran}

Saran dalam penelitian ini adalah: manajemen Bank papua cabang manado secara berkesinambungan harus mengontrol sistem informasi dan pengendalian intenal yang sudah di jalankan dan juga melakukan pembenahan pada standar operasional prosedur pemberian kredit, sumber daya manusia, kebijakan atau aturan main kredit guna meminimalisir risiko dalam pemberian kredit.

\section{DAFTAR PUSTAKA}

Anthony. 2012. Sistem Pengendalian Manajemen. Edisi Kedua. Kharisma Publishing Group. Tangerang.

Cahyani. 2016. Analisis Efektivitas Pengendalian Intern Pemberian Kredit Pada PD. Bank Perkreditan Rakyat Sleman. Universitas Sanatha Dharma Yogjakarta.

Dera. 2016. Analisis Efektivitas Sistem Pengendalian Internal Piutang Dan Kerugian Piutang Tak Tertagih PadaPT. Surya Wenang Indah Manado. Universitas Sam Ratulangi Manado.

George. H. Bodnar. 2015. Sistem Informasi Akuntansi. Edisi ke sembilan Andi. Yogyakarta.

George dan Wiliiam. 2012. Accounting Information Systems. Edisi Eleventh. Pearson Education International. Florida Atlantic University.

George dan William. 2009. Akuntansi Biaya. Edisi Keempat belas, Buku Satu. Salemba Empat. Jakarta.

Hastoni. 2006. Penerapan sistem pengendalian internal dalam meminimalkan kredit macet Pada PT. sosro KP sawangan. Sekolah Tinggi Ilmu Ekonomi Kesatuan Bogor.

Hansen. 2007. Sistem Informasi Akuntansi. Salemba Empat Jakarta.

Hansen dan Mowen. 2011. Akuntansi Manajerial. Edisi ke delapan. Salemba Empat Jakarta.

James. 2013. Accounting Information System. SI :south-western Cengage Learning.

Halim. Et al. 2013. Akuntansi Manajemen. Salemba Empat. Jakarta.

Krismiaji. 2015. Sistem Informasi Akuntansi Edisi keempat Penerbit dan Percetakan Sekolah Tinggi Ilmu Manajemen YKPN Yogyakarta.

Krismiaji dan Aryani. 2011. Akuntansi Manajemen. Edisi kedua. Sekolah Tinggi Ilmu Manajemen YKPN. Yogjakarta.

Khasmir. 2012. Bank dan Lembaga Keuangan Lainnya. Rajawali Pers. Jakarta. 